\title{
飲酒行動を決定する遺伝要因とその健康影響
}

\author{
竹下 達 也 \\ 大阪大学大学院医学系研究科社会環境医学講座 (環境医学)
}

\section{Genetic Factors Which Regulate Alcohol Drinking Behavior and Their Effects on Health Status}

\author{
Tatsuya TAKESHITA
}

Department of Social and Environmental Medicine, Osaka University Graduate School of Medicine, Osaka

\begin{abstract}
High alcohol sensitivity common among Orientals is mainly due to genetic polymorphism in the low $\mathrm{K}_{\mathrm{m}}$ aldehyde dehydrogenase $(A L D H 2)$ gene. The relation of the $A L D H 2$ genotype to alcohol sensitivity and drinking behavior was investigated in a Japanese occupational population. The frequency of alcoholassociated symptoms generally increased in the order of the typical homozygote, heterozygote, and atypical homozygote. Both drinking frequency and amounts of alcohol consumption were also significantly affected by the polymorphism. Polymorphism in the alcohol dehydrogenase $\beta$-subunit $(A D H 2$ gene) appeared to contribute to skin flushing post-alcohol exposure but not to alcohol drinking behavior. Multivariate analysis revealed that high alcohol consumption, the ALDH $2 * 1 /{ }^{*} 1$ genotype, and high daily hassles levels significantly contribute to the prevalence of those with a high problem-drinking score in an occupational population. In the study to assess the effects of the $A L D H 2$ polymorphism and alcohol use on the induction of chromosome alterations in peripheral lymphocytes, we found that lymphocytes from habitual drinkers with the atypical $A L D H 2$ genotypes had significantly higher frequencies of sister-chromatid exchange (SCE) than those from the typical ALDH2 genotype. We also measured acetaldehyde reversibly bound to hemoglobin (HbAA). In volunteers with the $A L D H 2^{*} 1 /^{*} 2$ genotype, the HbAA levels increased immediately after the drink and the elevated levels persisted up to $48 \mathrm{~h}$. Among male workers, HbAA levels were significantly correlated with the recent alcohol consumption levels in both the $A L D H 2^{*} 1 /^{*} 1$ and $A L D H 2^{*} 1 /{ }^{*} 2$ genotypes. However, the slope was much steeper in the $A L D H 2^{*} 1 /^{*} 2$ than in the $A L D H 2^{*} 1 /^{*} 1$. SCE and HbAA may be utilized as a good biomarker for health problems in the atypical ALDH2 genotype. Further extensive studies are required for evaluation of the interactive effects of genetic and environmental factors on alcohol-related health problems.
\end{abstract}

Key words: alcohol (アルコール), aldehyde dehydrogenase (アルデヒド脱水素酵素), alcohol dehydrogenase (アルコール脱水素酵素), polymorphism (多型), acetaldehyde (アセトアルデヒド)

\section{1.はじめに}

飲酒行動は, ライフスタイルの中でも喫煙や食事 とともに様々な成人病の危険度に影響を与える重要 な要因の一つである。日本人の成人一人あたりアル コール消費量は, $8.5 \ell /$ 年とされており, 世界的にみ て決して多い方ではない1。しかしながら，後述する 遺伝要因によって遺伝的に多量飲酒のできない群が 半数近く存在していることを考慮すると, むしろア ルコール消費量は世界各国と比較してもトップクラ

受付 1998年12月3日 受理 1999年2月4日

Reprint requests to: Tatsuya TAKESHITA,

Department of Social and Environmental Medicine (F1),

Osaka University Graduate School of Medicine, 2-2 Yamada-oka, Suita, Osaka 565-0871, Japan

TEL: +81(6)6879-3922 FAX: +81(6)6879-3923

e-mail takesita@envi.med.osaka-u.ac.jp
スに近く2), 飲酒の健康影響に関する研究は重要な意 義を有している。

日本人を含む東洋人はアルコール感受性に著しい 個体差があり, 約半数においては, 飲酒時に顔面紅 潮（フラッシング), 頭痛, 動悸などのアルコール過 敏症状が出現する。このアルコール感受性に関する 著しい人種差については，1972年にWolffによっては じめて定量的なデータが報告された ${ }^{3)}$ 。その後東洋人 におけるエタノール代謝関連酵素の多型を中心に多 数の研究がなされてきた。

本稿では, アルコール感受性・飲酒行動を規定す る遺伝要因およびその健康影響に関するこれまでの 知見を著者らの結果を中心に概説する。

\section{2.アルコール感受性の遺伝的背景}




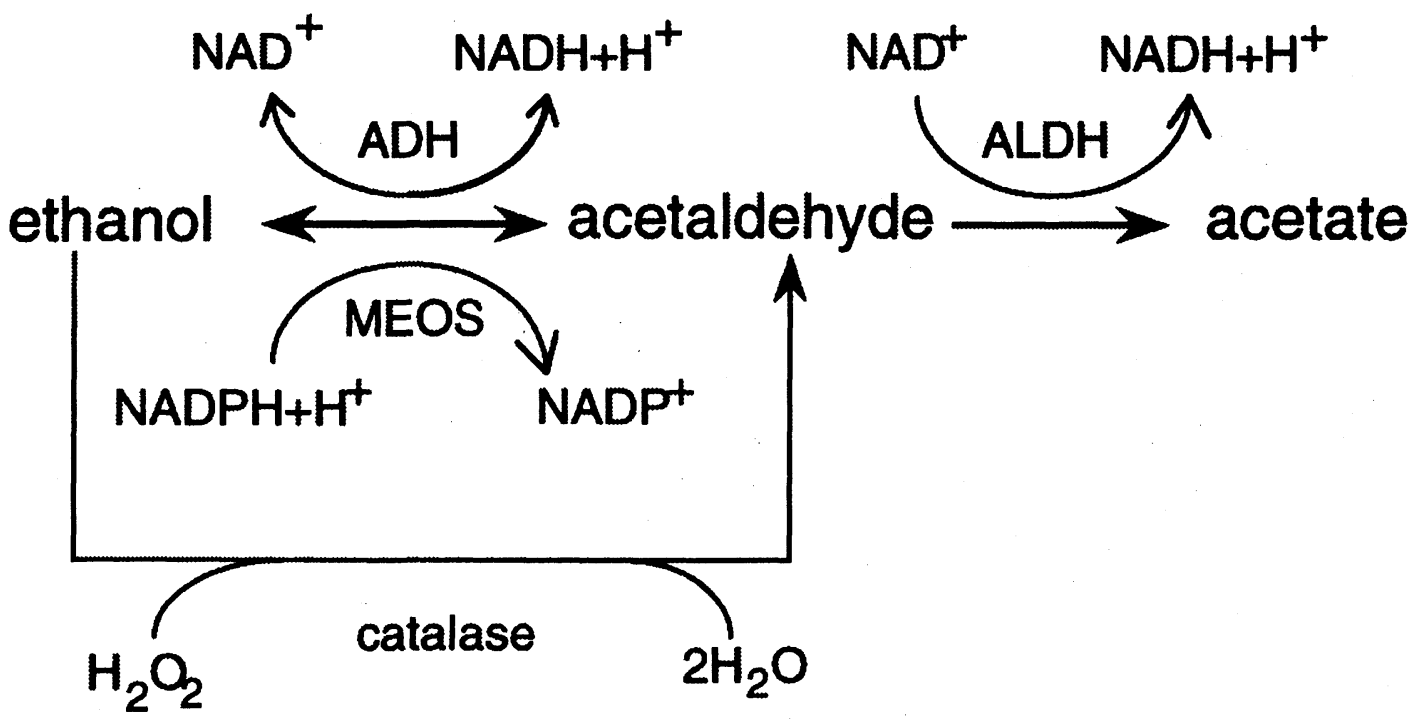

Fig. 1 Pathways for the metabolism of ethanol. MEOS denotes microsomal ethanol oxidizing system.

生体内に䝮取されたエタノールは，主に肝臓にお いて，アルコール脱水素酵素(ADH)によってアセトア ルデヒド(AcH)に変換され，さらにアルデヒド脱水素 䤃素(ALDH)によって酷酸に代謝される(Fig. 1)。細胞 質に存在するADHのバイパスとして，小胞体に存在 するミクロソームエタノール酸化系(MEOS)がある。 その主体はチトクロームP450の中の $2 \mathrm{E} 1$ サブタイプで あり，飲酒によって䤃素活性が立進することが知ら れている。

ALDHは，10種類が知られているが，AcHの代謝能 カが最も高いのは，ミトコンドリアに局在している ALDH2である。Km值が3.4 $\mu \mathrm{M}$ と低いためAcHの代謝 能力が高(4)。ALDH2の遺伝子は, Hsu et al. . $^{\text {に }}$ により そのcDNA遺伝子配列が決定され，12番染色体の長腕 末端にマッピングされている。ALDH2遺伝子の変異 型アリル $(A L D H 2 * 2)$ は, $A L D H 2$ 遺伝子のエクソン 12 にある487番目のアミノ酸GluをコードするGAAとい う塩基配列がLysをコードするAAAに変化するという

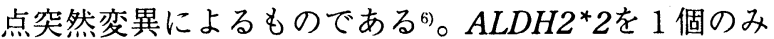
保有するへテロ型においてもフラッシング等のアル コール高感受性を示すことから，変異型が優性に発 現することが判明している7.8)。通常型アリル $\left(A L D H 2^{*} 1\right)$ を 2 個有する通常型木モ $\left(A L D H 2^{*} 1{ }^{*} 1\right)$ のみが扔酒に強い，いわゆる「ノンフラッシャー」 であり, 残りのへテロ型 $\left(A L D H 2^{*} 1 /{ }^{*} 2\right)$ と変異型ホモ $\left(A L D H 2 * 2 /{ }^{*} 2\right)$ とが，いわゆる「フラッシャー」を構 成している。

Harada et al.9)及びMizoi et al..$^{10}$ は, ALDH2の变異型 では，エタノール負荷後の血中AcH濃度が通常型より も明らかに高いことを明らかにした。またアルコー ル依存症ではALDH2の変異型の頻度が $2.3 \%$ （健康人 では $41 \%$ ）と低いことが報告され，ALDH2の変異は アルコール依存症の発症に対して予防的に働くこと
が示された11)。

3. 職域集団における $A L D H 2$ 遭伝子型とアルコール 感受性，飲酒行動との関連性の検討

これまで日本人のある定義された集団における $A L D H 2$ 遺伝子型とアルコール感受性, 飲酒行動との 関連に関して包括的に検討した報告は見当たらなか った。そこで我々は，当教室が健康管理に関わって いる中規模製造業事業所従業員（男性424名，女性 100名）を対象として，これらの検討を行った ${ }^{12-14) 。 ~}$

$A L D H 2$ 遺伝子型の検討にはPCR-RFLP法を用いた。 末梢白血球よりDNAを抽出しこれを鋳型として PCR法によりエクソン12の増幅を行った ${ }^{133}$ 。一方のプ ライマーの1箇所に人工的にミスマッチをおこすこ とによって通常型アリルのみ制限酵素Ksp632Iの認識 部位が生じる。増幅後にこの酵素で消化することに より，3つの遺伝子型が明瞭に判定された(Fig. 2)。

また自記式質問表によって，飲酒時の症状㧍よび 日頃の飲酒行動，日常いらだち事等の情報を得た。 質問表記入後にエタノールパッチテスト ${ }^{15)}(70 \%$ エ夕 ノール液 $100 \mu 1$ を 7 分間貼付）も実施した。

$A L D H 2$ 遺伝子型の頻度は男女差なく，欧米人と同 $\begin{array}{lllllllllll}1 & 2 & 3 & 4 & 5 & 6 & 7 & 8 & 9 & 10 & M\end{array}$

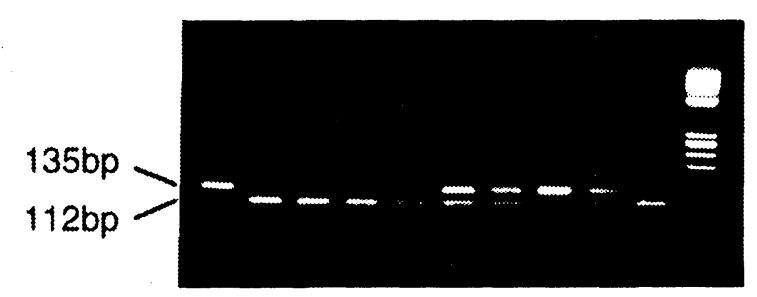

Fig. 2 Gel electrophoresis of PCR products of $A L D H 2$ exon 12 (lane 2-5,10, $A L D H 2^{*} 1{ }^{*} 1$; lane 6,7,9, $A L D H 2^{*} 1{ }^{*} 2$; lane $1,8, A L D H 2{ }^{*} 2 /{ }^{*} 2$ ). 

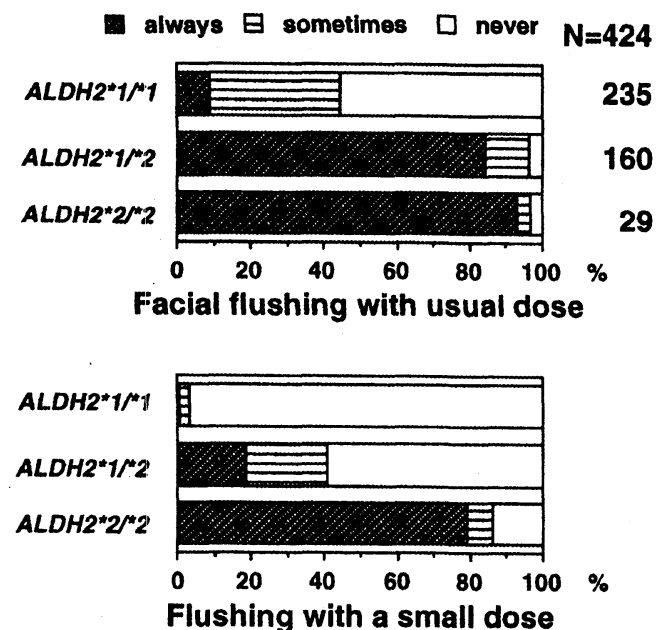

Fig. 3 Relationship between the $A L D H 2$ genotype and flushing among the male workers. A small dose means onequarter of a glass of beer ${ }^{13}$.
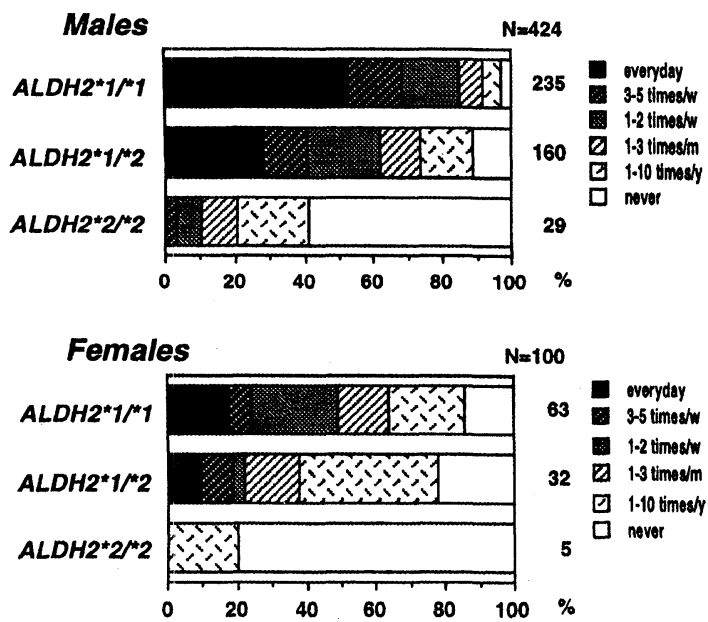

Fig. 4 Relationship between the $A L D H 2$ genotype and drinking frequency among the male workers ${ }^{13}$.

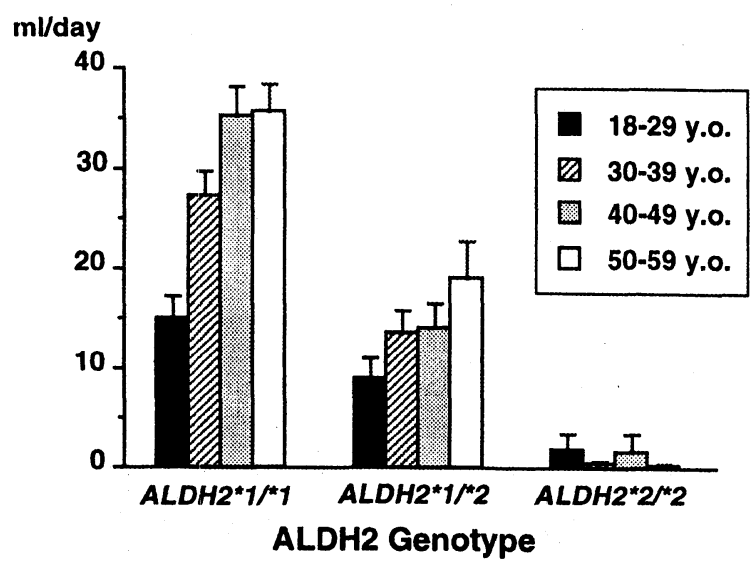

Fig. 5 Relationship between the $A L D H 2$ genotype, age and average amounts of alcohol consumption among the male workers.
じ $A L D H 2{ }^{*} 1 /^{*} 1$ が男 $55.4 \%$ ，女 $63.0 \%, A L D H 2 * 1 /{ }^{*} 2$ が 男 $37.7 \%$ ，女 $32.0 \%, A L D H 2 * 2{ }^{*} 2$ が，男 $6.8 \%$ ，女 $5.0 \%$ であった。

以下対象者数の多い男性において解析を行った。 飲酒時に常に顔が赤くなる人の割合が， $A L D H 2 * 1 / * 2$ と ALDH2*2/*2では $80 \%$ を超えている のに対して，ALDH2*1/*1では9\%であった(Fig. 3)。 ビールを少量（コップに1/4杯）飲酒時に赤くなる人 の割合は, $A L D H 2 * 1 /{ }^{*} 1$ が $0.4 \%, A L D H 2 * 1 /{ }^{*} 2$ が $18.8 \%, A L D H 2 * 2 /{ }^{*} 2$ が $79.3 \%$ と，変異型アリル $A L D H 2 * 2 か ゙$ 多いほど感受性の高いことが示唆された。 動悸, 頭痛, 眠気等の症状も同様に, $A L D H 2^{*} 1 /{ }^{*} 1$, $A L D H 2 * 1 /{ }^{*} 2, A L D H 2 * 2{ }^{*} 2$ の順に割合が高くなっ ていた ${ }^{13)}$ 。

これらの飲酒時症状の多くは, 血中AcH濃度が高值 となったために生じるものと考えられる。飲酒時の 頻脈および動悸は, 血中 $\mathrm{AcH}$ 濃度上昇に伴って AdrenalinおよびNoradrenalinが分泌されるためである ことが示唆されている16。また飲酒時のフラッシング に関しては，抗ヒスタミン剤17, アスピリン18), opiate

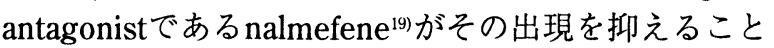
から, AcH濃度の上昇に伴うヒスタミンの分泌, プロ スタグランジン系およびopiate系がフラッシングに関 与しているとみられている。

以上の解析結果より, 高感受性群が 2 つの群 (中 間的感受性群と高度感受性群）に分かれることが判 明した。表現型とALDH2遺伝子型との比較より, 低 感受性群が $A L D H 2 * 1{ }^{*} 1$, 中間的感受性群が $A L D H 2{ }^{*} 1 /{ }^{*} 2$, そして高感受性群が $A L D H 2^{*} 2 /{ }^{*} 2$ に 対応することが明らかになった。ALDH2*1/*2と $A L D H 2 * 2 /{ }^{*} 2$ との間の表現型の差については, 集団 レベルではじめて明らかにすることができた。

日頃の飲酒頻度は，アルコール感受性をよく反映 しており，ほほ毎日飲酒している者の割合は， $A L D H 2 * 1 /{ }^{*} 1$ が $52.3 \%, A L D H 2{ }^{*} 1 /{ }^{*} 2$ は $28.1 \%$, $A L D H 2 * 2 / * 2$ は0.0\%であった(Fig. 4)。飲酒頻度と 1 回の飲酒量から 1 日平均 (土標準偏差)の飲酒量 (純工 夕ノール換算）を求めると, $A L D H 2 * 1 /{ }^{*} 1$ が最も多 く28.4 $\pm 22.2 \mathrm{ml} /$ 日, $A L D H 2^{*} 1 /{ }^{*} 2$ が $13.5 \pm 16.5 \mathrm{ml} /$ 日，

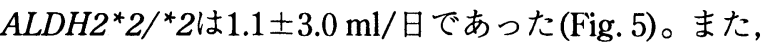

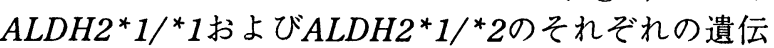
子型の中では, 中高年者の方が, 若年者よりも飲酒 量が多くなっていた。

ALDH2がテトラマーであることを考慮すると，

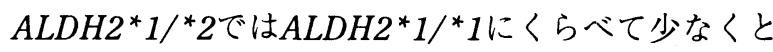
も $1 / 16$ 程度のALDH活性は有すると考えられる 20.21)。 一方 $A L D H 22^{*} 2{ }^{*} 2$ では $100 \%$ 変異型サブユニットで構 成されているため酵素活性はゼロと考えられる。こ

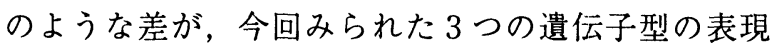
型の差を生んだと解釈される。 
日衛誌（Jpn. J. Hyg.）第54巻 第 2 号 1999年 7 月

Table 1 Items and weighted scores for ALST (Alcohol Sensitivity Screening Test) Do you have the following symptoms during alcohol consumption?

\begin{tabular}{llll}
\hline & $\begin{array}{l}\text { always } \\
\text { present }\end{array}$ & $\begin{array}{l}\text { sometimes } \\
\text { present }\end{array}$ & absent \\
\hline Facial flushing & 3.8 & 1.1 & 0.0 \\
Flushing elsewhere & 1.6 & 1.1 & 0.0 \\
Palpitations & 2.3 & 1.3 & 0.0 \\
\hline
\end{tabular}

\section{ALDH2遺伝子型のスクリーニングテスト}

我々は，今回検討した飲酒後の諸症状の中で，わ ずか 3 項目の質問紙法(ALST; Table 1)によって, $A L D H 2^{*} 1{ }^{*} 1$ と変異型 $\left(A L D H 2^{*} 1 /{ }^{*} 2\right.$ と $A L D H 2 * 2 /{ }^{*} 2$ を合わせた群)を $90 \%$ 弱の精度で判定し得ることを， 判別分析によって見いだした(Fig. 6) ${ }^{22)}$ 。遺伝子型解析 が困難な対象集団や大きなサンプルサイズの対象集 団に対する疫学的な研究においては実用価值がある と考えられる。これに対して，エタノールパッチテ ストでは $A L D H 2 * 1 /{ }^{*} 1$ が79\%, ALDH $2{ }^{*} 1 /{ }^{*} 2$ が $84 \% し$ か正しく判定できなかった。パッチテストは飲酒経 験の乏しい学校保健領域等の対象者に対しての健康 教育のツールとしてその意義は大きいが, その精度 に関する基礎的検討も重要である。

\section{ADH2遺伝子型とアルコール感受性との関連}

日本人など東洋人においては，ADHを構成するサ ブユニット $\alpha, \beta, \gamma$ のうち $\beta$ の変異型が, $85 \%$ 以

\section{Males $(N=424)$}

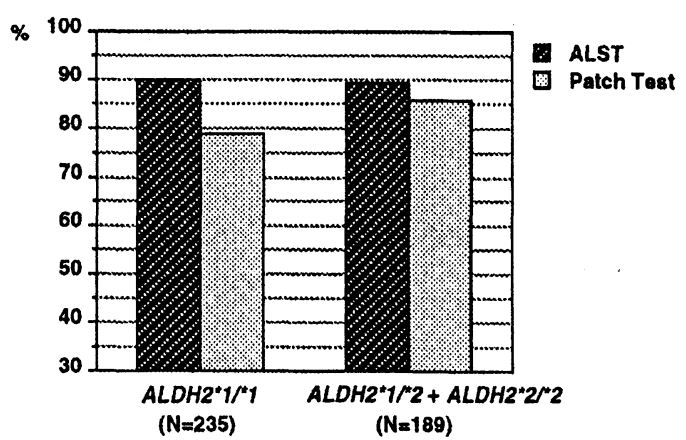

\section{Females $(\mathrm{N}=100)$}

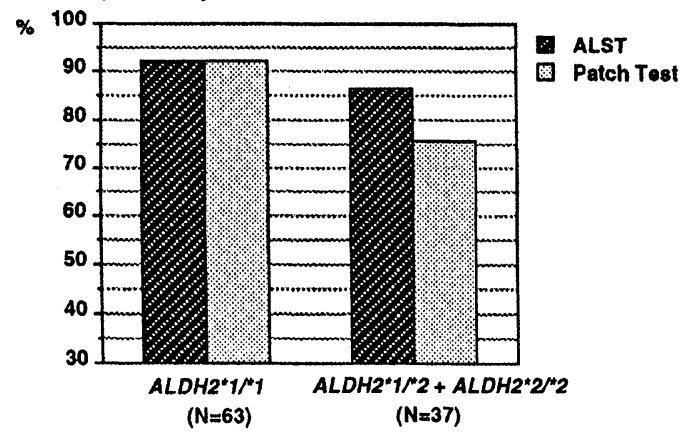

Fig. 6 Reliability of screening tests (ALST and ethanol patch test) for the $A L D H 2$ polymorphism among the male and female workers ${ }^{22}$.
上の頻度で存在することが見いだされた23)。変異型は $\mathrm{AcH}$ の変換速度が速いことから，このADH2（ $\beta$ subunitをコードする遺伝子）の遺伝子多型がアルコ 一ル高感受性の主な原因ではないかと考えられた ${ }^{23)} 。$ しかし常にフラッシング症状を呈する人は東洋人の 約 $50 \%$ にすぎないことから，その後発見された上述 のALDH2の遺伝子型の方が有力とされるに至った。

Fig. 3のように, $A L D H 2$ 遺伝子型と飲酒時のフラッ シングの有無との関連性は，85-90\%にとどまってい る。一致しない部分, つまり $A L D H 2^{*} 1{ }^{*} 1$ であるの に常にフラッシングが出現する群，及び $A L D H 2^{*} 1{ }^{*} 2$ であるのに常にフラッシングのみられない群にはど のような因子が関連しているのでろうか。ADH2遺伝 子型は，肝臓におけるアルコール代謝には影響を及 ぼしていないとはいえ ${ }^{24)}$ ，東洋人に多い変異型ADH2 はin vitroでは迅速にAcHを産生することが報告されて いる ${ }^{25)}$ 。また最近 $A D H 2$ 遺伝子型がアルコール依存症 やアルコール性肝障害の独立した危険因子であるこ とが示唆されている26-29)。そこで我々の対象者につい ても $A D H 2$ 遺伝子型を調べてみた ${ }^{14)}$ 。方法は既に報告 されているPCR-RFLP法である30)。

Fig. 7に示すように，統計学的な差はないものの， $A L D H 2^{*} 1{ }^{*} 1$ で常にフラッシングが出現する者は必 ず変異型のADH2アリルを保有していた。一方 $A L D H 2{ }^{*} 1{ }^{*} 2$ の中では, $A D H 2^{*} 1{ }^{*} 1$ が他のADH2遺 伝子型よりも有意にフラッシングの出現率が低くな っていた。エタノールパッチテストの結果も，先ほ どのビールコップに 1 杯でのフラッシングと全く同 様の結果となり，しかもADH2遺伝子型間の差が顕著 であった。これらの結果は，ADH2遺伝子型が皮膚の フラッシングに何らかの影響を与えることを示唆し ている。パッチテストで $A D H 2$ 遺伝子型の影響がより 顕著であったことから，皮膚に発現しているADH2の 役割がALDH2 と並んで大きい可能性が考えられる。 すなわち変換速度の速い変異型ADH2は，皮膚局所に おいてAcHを多く産生してフラッシング反応を出現さ せる方向に働くことが考えられる。しかし我々の対 象者においては $A D H 2^{*} 1 /{ }^{*} 1$ は $6.6 \%$ と少数であり，今

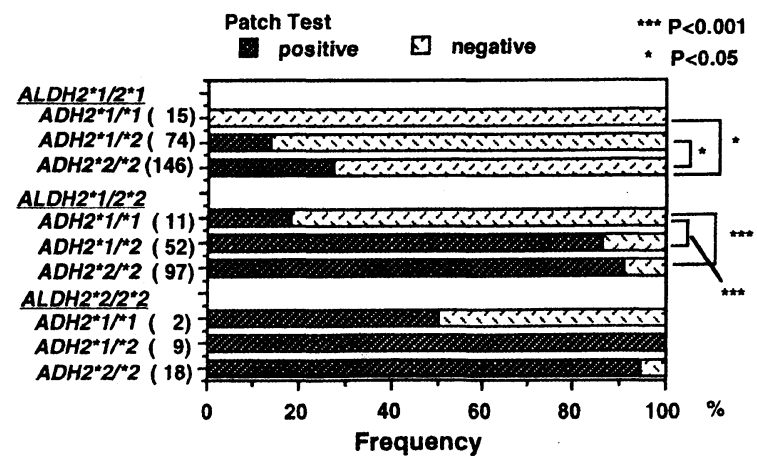

Fig. 7 Effects of the $A L D H 2$ and $A D H 2$ genotypes to the results of the alcohol patch test ${ }^{14}$ ). 
回観察された $A D H 2$ 遺伝子型の影響を確認するにはか なり大きな集団での調査が必要である。

一方データは示さないが, 飲酒頻度や飲酒量には $A D H 2$ 遺伝子型の影響はほとんどみられなかった ${ }^{14) 。}$

\section{6. 問題飲酒行動に関連する遗伝・環境要因の検討}

アルコール依存症の危険度は，ALDH2遺伝子型の 強い影響を受ける。Harada et al.によると，依存症の

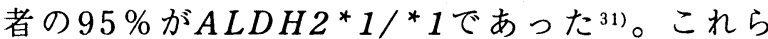
$A L D H 2^{*} 1{ }^{*} 1$ の人が依存症に至る道筋には，様々な 環境要因も加わっているはずである。

我々は上述の対象者集団に対して，日本で広く用 いられている久里浜式アルコール依存症スクリーニ

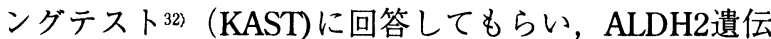
子型やストレッサーとの関連を検討した ${ }^{33)}$ 。KASTは， 健康な人と依存症の人とを質問紙で高い信頼度で判 別しうる。一方，日常いらだち事の質問表にも回答 してもらい,ストレッサーの指標とした。

KASTでは，0 点以上を問題飲酒群（2点以上を重 篤問題飲酒群）としている。筆者らの調査では，こ の問題飲酒群の頻度が，ALDH2*1/*2では $5 \%$ と低か ったのに対して,$A L D H 2 * 1 /{ }^{*} 1 て ゙ は 18 \%$ と高かった ${ }^{33) 。 ~}$ さらにALDH2*1/*1を年齢で 2 群に分けてみると， 40 歳未満の $10 \%$ に対して 40 歳以上では $26 \%$ と非常に 高い頻度であった。

KAST得点と，日常いらだち事との関連についてみ ると, Fig. 8のように, 最も問題飲酒群の多い40歳以 上の $A L D H 2 * 1{ }^{*} 1$ においてのみ，日常いらだち事が 多いほどKAST得点の平均値が高く，両者の間に正の 相関がみられた。ALDH2*1/*1群について多重ロジ スティック回帰分析を行った結果，KAST高得点に関 連する要因として，飲酒量，年齢，日常いらだち事

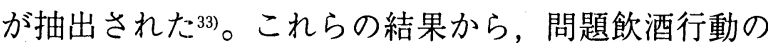
予防には，ALDH2*1/*1の中高年における適切なス トレスマネージメントが重要と考えられた。

今回の検討では，KAST得点と $A D H 2$ 遺伝子型との 関連は見出されなかったが，Higuchi et al.は，日本人 集団における調査において，両者の関連を報告して

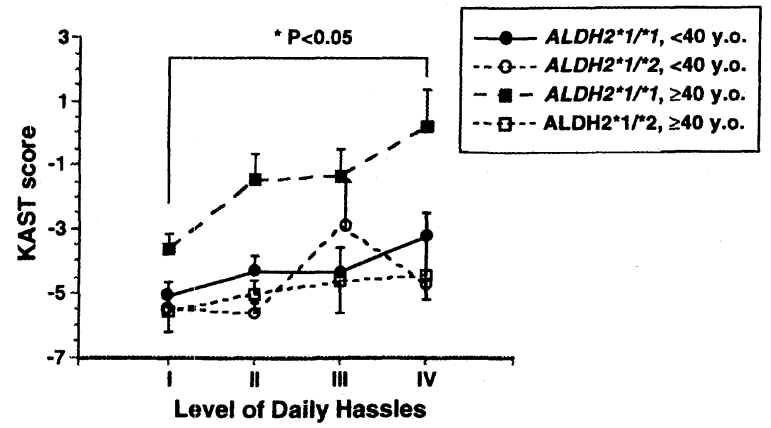

Fig. 8 Effects of the $A L D H 2$ genotype, age, and level of daily hassles on the KAST score.
いる34)。アルコール依存症と $A D H 2$ 遺伝子型との有意 な関連性を示す報告は最近増加している ${ }^{26-29) 。 ~}$

Thomasson et al.はADH2遺伝子型がアルコール依 存症の危険因子となることを台湾の中国人において 報告した ${ }^{26)}$ 。また日本においても，ADH2遺伝子型か $A L D H 2$ 遺伝子型と独立にアルコール依存症の危険因 子となることが示されている ${ }^{29)} 。$ 上に述べたように， $A D H 2$ 遺伝子型がエ夕ノールおよびAcHの全身的な代 謝に及ほす影響はほとんどないと考えられており， $A D H 2$ 遺伝子型が依存症の危険因子となる機序は今の 所不明である。

\section{7. アルコール高感受性の習慣的飲酒者における染色 体変異量の増加}

姉妹染色分体交換(SCE) は，DNA損傷の指標の 1 つ であり，発がんのバイオマーカーの一つとして注目 されている。SCE頻度は，契煙をはじめとする悪い生 活習慣の影響により上昇することが報告されている35。 我々は，上と同じ職域集団の協力を得て，血液り ンパ球のSCE頻度を測定し， $A L D H 2$ 遺伝子型および 飲酒行動がこの染色体変異量に及ぼす影響を解析し た ${ }^{36)}$ 。Fig. 9に示すように, ALDH2の変異型でありな がら習慣的に飲酒している群のみが，他の群よりも baseline SCE頻度が有意に高いことが示された。この 群は，習慣的な飲酒により，常に高濃度のAcHの内的 曝露を受けている群である。AcHはin vitroの系におい て強力な染色体変異誘発活性を有している ${ }^{37)}$ こか ら，我々はこの高濃度AcH曝露を介してbaseline SCE 頻度の上昇を来したものと考えている。我々は最近, 同じ職域集団において, ALDH2の変異型でありなが

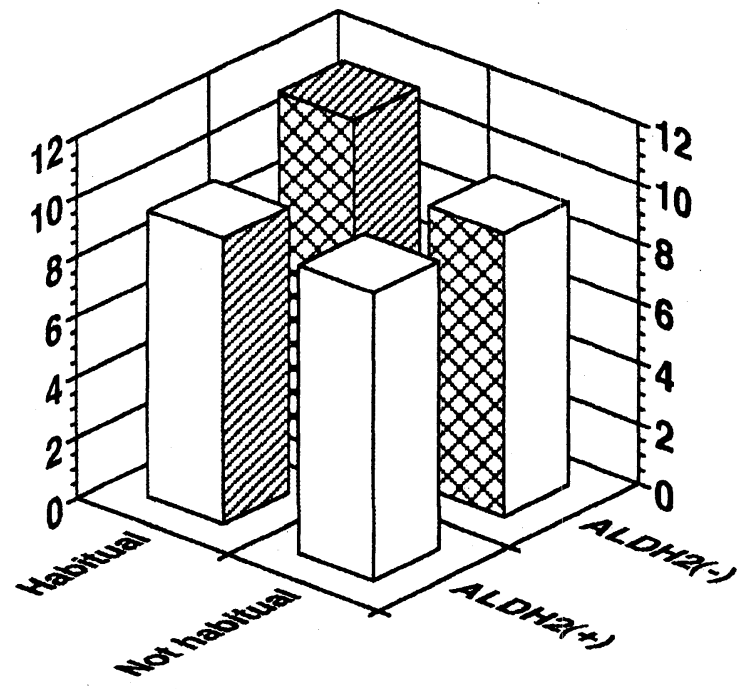

Fig. 9 Baseline SCE frequency in blood lymphocytes from the subjects with the different $A L D H 2$ genotypes $\left(\mathrm{ALDH} 2(+), A L D H 2^{*} 1 /^{*} 1 ; \mathrm{ALDH} 2(-), A L D H 2^{*} 1 /^{*} 2\right.$ and $\left.A L D H 2^{*} 2{ }^{*} 2\right)^{36)}$. 

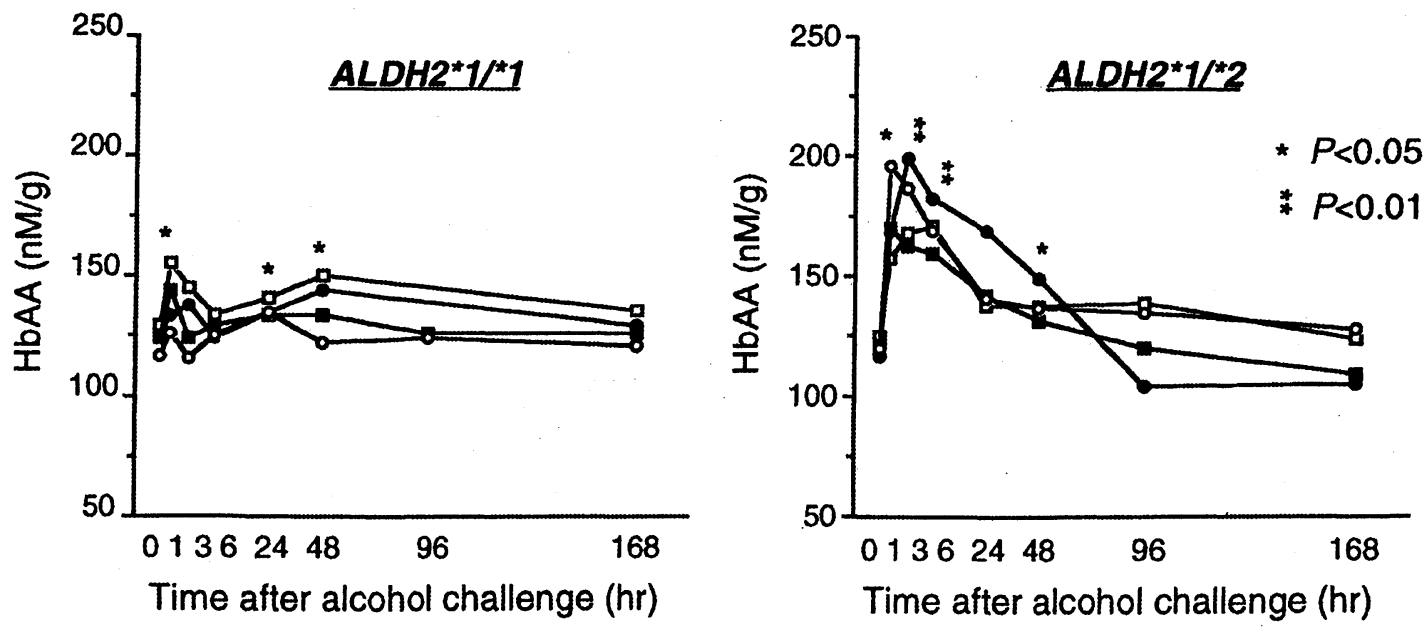

Fig. 10 Time-dependent changes of the HbAA levels before and after drinking $0.4 \mathrm{ml} / \mathrm{kg}$ ethanol ${ }^{40}$.
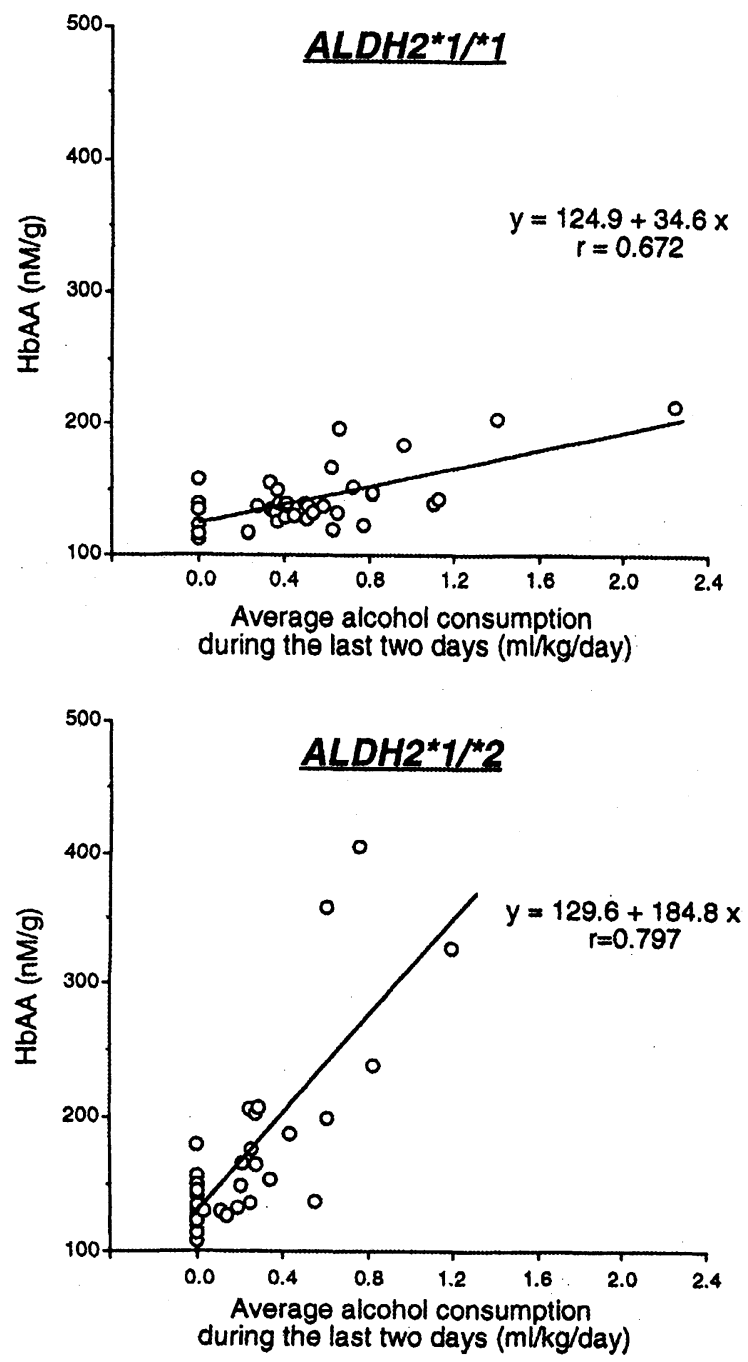

Fig. 11. Correlations of the HbAA levels with average amounts of alcohol consumption during the last two days in the $A L D H 2^{*} 11^{*} 1(\mathrm{n}=4)$ and $A L D H 2^{*} 1 /^{*} 2(\mathrm{n}=4)$ genotypes ${ }^{40)}$.
ら習慣的に飲酒している群では，多核白血球の酸化 的DNA損傷量の増加を観察している ${ }^{38)}$ が, これも $\mathrm{AcH}$ 曝露量の差を反映している可能性が考えられる。

\section{8. アルコール高感受性者における飲酒後のAcH蛋白 付加体量の増加}

前節で述べたように，アルコール感受性の高い $A L D H 2^{*} 1 /{ }^{*} 2$ や $A L D H 2{ }^{*} 2 /{ }^{*} 2$ の人が飲酒すると, $\mathrm{AcH}$ が体内で高濃度となるが，このAcHは動物において発 癌性が証明されており ${ }^{399}$ ，ヒトにおいても発がん危険 度の上昇等の慢性影響が懸念されている。

我々は，ボランティアにお酒 $(0.4 \mathrm{ml} / \mathrm{kg})$ を実際に飲 んでもらって，赤血球へモグロビンに可逆的に結合 したAcH付加体量(HbAA)をHPLCと蛍光検出器を用い て測定した ${ }^{40)}$ 。HbAA量は, Peterson et al. ${ }^{41)}(1987) の$ 方 法に従い，酸性の条件下でcyclohexane-1，3-dione と 反応させて蛍光産物を生成し, HPLC, 蛍光検出器 (excitation, 370nm; emission, 450nm)により定量を行 った。

結果は, $A L D H 2 * 1 /{ }^{*} 2$ において飲酒 1 時間後より HbAAが顕著に増加し，24〜48時間後まで飲酒前にく らべて高値を示した(Fig. 10)。従って検診時等の随時 採血のサンプルでも飲酒量の指標として用いうる可 能性が高い。実際，上に述べた職域集団の協力を得 て, 検診時の血液サンプル中のHbAAを測定した所， $A L D H 2^{*} 1{ }^{*} 1, A L D H 2^{*} 1{ }^{*} 2$ ともに過去 2 日間の平 均飲酒量と有意な相関がみられたが，ALDH2*1/*2 は特に良好な相関 $(\mathrm{r}=0.797)$ が観察された(Fig. 11)。 また回帰直線の傾きは $A L D H 2{ }^{*} 1 /{ }^{*} 2$ の方が $A L D H 2{ }^{*} 1{ }^{*} 1$ より数倍大きかった。

サンプル数を增やして解析を行った所， $A L D H 2^{*} 1 /{ }^{*} 2$ の中で習慣的に飲酒している者は，回 㷌直線による予測值よりも高値を示す傾向がみられ た。HbAA量について, 重回帰分析を行った結果, 


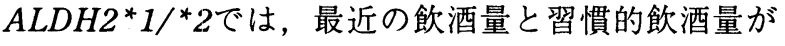
ともに高度に $(\mathrm{P}<0.001)$ 有意であった。一方, $A L D H 2^{*} 1{ }^{*} 1$ では，最近の飲酒量とのみ相関がみら れた。以上のことから $A L D H 2 * 1 /{ }^{*} 2 て ゙ は$, 習慣的飲 酒によりHbAAが蓄積することが示唆された。

最近アルコール依存症者および多量飲酒者におけ

る，食道がん発症のリスクは，ALDH2*1/*2が $A L D H 2^{*} 1{ }^{*} 1$ に比べて10倍近い関連性を示すことが 報告されている ${ }^{42,43)}$ 。がん以外にも, 飲酒誘発喘息の 発症リスクとも有意な関連性を示すことが報告され てきた ${ }^{44)}$ 。従って，これらの疾患は飲酒時の $\mathrm{AcH}$ への 内的曝露が疾患発症に重要な影響を与えている可能 性が大きい。

以上をまとめると, HbAAはAcHへの内的曝露量の 良い指標となることが示された。HbAAは，AcHが関 与する上に挙げたような健康影響の指標としても期 待される。

\section{9. おわりに}

$A L D H 2$ 遺伝子型は，飲酒時のフラッシングという， 我々には極めてなじみの深い現象に密接に結びつい た遺伝子の変異であるが, 健康行動や様々な健康問 題にも関連した重要な問題である。それぞれの遺伝 子型について適正な飲酒量を推定することは, 健康 増進の観点から重要な課題である。

今後の予防医学においては，ライフスタイル等の コントロール可能な環境要因と関連の深い様々な遺 伝要因の解析に積極的に取り組み, 健康事象におけ る遺伝・環境要因の交絡影響を明らかにし，ヘルス プロモーションへの応用をはかることが重要と考え られる。

\section{謝 辞}

本研究の実施に際し, 終始御指導を賜りました大 阪大学大学院医学系研究科の森本兼童教授に深甚な る謝意を表します。また研究実施に御協力下さった 大阪大学大学院医学系研究科社会環境医学講座環境 医学教室の教室員および教室外の共同研究者の方々 にも厚く御礼申し上げます。

\section{文献}

1) Anonymous. Health and Welfare Statistics in Japan. Tokyo, Health and Welfare Statistics Association, 1998.

2) Anonymous. Ninth special report to the U.S. Congress on alcohol and health, NIH Publication No. 97-4017. National Institute of Health, National Institute on Alcohol Abuse and Alcoholism, 1997.

3) Wolff PH. Ethnic differences in alcohol sensitivity.
Science $1972 ； 175 ： 449-50$.

4) Agarwal DP, Goedde HW. Alcohol metabolism, alcohol intolerance, and alcoholism. Berlin : Springer-Verlag, 1990.

5) Hsu LC, Tani K, Fujiyoshi T, Kurachi K, Yoshida A. Cloning of cDNAs for human aldehyde dehydrogenases 1 and 2. Proc Natl Acad Sci USA $1985 ; 82: 3771-5$.

6) Yoshida A, Huang I, Ikawa M. Molecular abnormality of an inactive aldehyde dehydrogenase variant commonly found in Orientals. Proc Natl Acad Sci USA 1984 ; 81 : 248-61.

7) Crabb DW, Edenberg HJ, Bosron WF, Li TK. Genotypes for aldehyde dehydrogenase deficiency and alcohol sensitivity. The inactive ALDH2 $2^{2}$ allele is dominant. J Clin Invest $1989 ; 83: 314-6$.

8) Goedde HW, Singh S, Agarwal DP, Fritze G, Stapel K, Paik YK. Genotyping of mitochondrial aldehyde dehydrogenase in blood samples using allelespecific oligonucleotides: Comparison with phenotyping in hair roots. Hum Genet $1989 ; 81$ : 305-7.

9) Harada S, Agarwal DP, Goedde HW. Aldehyde dehydrogenase deficiency as cause of facial flushing reaction to alcohol in Japanese. Lancet $1981 ; 2: 982$.

10) Mizoi Y, Tatsuno Y, Adachi I, et al. Alcohol sensitivity related to polymorphism of alcoholmetabolizing enzymes in Japanese. Pharmacol Biochem Behav 1983 ; 18(Suppl 1) : 127-33.

11) Harada S, Agarwal DP, Goedde HW, Tagaki S, Ishikawa $\mathrm{B}$. Possible protective role against alcoholism for aldehyde dehydrogenase deficiency in Japan. Lancet $1982 ; 2: 827$.

12) Takeshita $T$, Morimoto $K$, Mao $X$, Hashimoto $T$, Furuyama J. Phenotypic differences in low $\mathrm{K}_{\mathrm{m}}$ aldehyde dehydrogenase in Japanese workers. Lancet $1993 ; 341: 837-8$.

13) Takeshita $T$, Morimoto $K$, Mao $X$, Hashimoto $T$, Furuyama J. Characterization of the three genotypes of low $\mathrm{K}_{\mathrm{m}}$ aldehyde dehydrogenase in a Japanese population. Hum Genet 1994 ; 94 : 21723.

14) Takeshita T, Mao $X Q$, Morimoto $K$. The contribution of polymorphism in the alcohol dehydrogenase $\beta$-subunit to alcohol sensitivity in a Japanese population. Hum Genet 1996 ; 97 : 40913.

15) Muramatsu T, Higuchi $S$, Shigemori $K$, et al. Ethanol patch test. A simple and sensitive method for identifying ALDH phenotype. Alcohol Clin Exp 
Res $1989 ; 13: 229-31$.

16) Ijiri I. Studies on the relationship between the concentrations of blood acetaldehyde and urinary catecholamine and the symptoms after drinking alcohol. Jpn J Stud Alcohol 1974 ; 9 : 35-59.

17) Miller NS, Goodwin DW, Jones FC, et al. Antihistamine blockade of alcohol-induced flushing in Orientals. J Stud Alcohol 1988； $49: 16-20$.

18) Truitt EB, Gaynor CR, Mehl DL. Aspirin attenuation of alcohol-induced flushing and intoxication in Oriental and Occidental subjects. Alcohol Alcoholism 1987 ; Suppl 1 : 595-9.

19) Ho SB, DeMaster EG, Shafer RB, et al. Opiate antagonist nalmefene inhibits ethanol-induced flushing in Asians: a preliminary study. Alcohol Clin Exp Res $1988 ; 12: 705-12$.

20) Shibuya A, Yoshida A. Genotypes of alcoholmetabolizing enzymes in Japanese with alcohol liver diseases: A strong association of the usual Caucasian-type aldehyde dehydrogenase gene $\left(\mathrm{ALDH}_{2}{ }^{1}\right)$ with the disease. Am J Hum Genet $1988 ; 43: 744-8$.

21) Takeshita T, Morimoto K. Effects of genetic polymorphisms in alcohol-metabolizing enzymes on alcohol hypersensitivity and alcohol-related health problems in Orientals. Environ Health Prev Med $1996 ; 1: 1-8$.

22) Takeshita T, Morimoto K. Development of a questionnaire method to discriminate between typical and atypical genotypes of low $\mathrm{K}_{\mathrm{m}}$ aldehyde dehydrogenase in a Japanese population. Alcohol Clin Exp Res 1998 ; 22 : 1409-13.

23) Stamatoyannopoulos G, Chen SH, Fukui M. Liver alcohol dehydrogenase in Japanese: high population frequency of atypical form and its possible role in alcohol sensitivity. Am J Hum Genet 1975 ; 27 : 789-96.

24) Mizoi Y, Yamamoto K, Ueno Y, Fukunaga T, Harada S. Involvement of genetic polymorphism of alcohol and aldehyde dehydrogenases in individual variation of alcohol metabolism. Alcohol Alcohol $1994 ; 29: 707-10$.

25) Yin SJ, Bosron WF, Magnes LJ, Li TK. Human liver alcohol dehydrogenase: purification and kinetic characteristics of the $\beta 2 \beta 2, \beta 2 \beta 1$, and $\beta 2 \gamma 1$ "Oriental" isozymes. Biochemistry $1984 ; 23$ : 584753.

26) Thomasson HR, Edenberg HJ, Crabb DW, et al. Alcohol and aldehyde dehydrogenase genotypes and alcoholism in Chinese men. Am J Hum Genet $1991 ; 48: 677-81$.
27) Nakamura K, Suwaki H, Matsuo Y, Ichikawa Y, Miyatake R, Iwahashi K. Association between alcoholics and the genotypes of ALDH2, ADH2, ADH3 as well as P-4502E1. Jpn J Alcohol Drug Dependence $1995 ; 30: 33-42$.

28) Chao Y-C, Young T-H, Tang H-S, Hsu C-T. Alcoholism and alcoholic organ damage and genetic polymorphisms of alcohol metabolizing enzymes in Chinese patients. Hepatology 1997 ; $25: 112-7$.

29) Higuchi S, Matsushita S, Murayama M, Takagi S, Hayashida $M$. Alcohol and aldehyde dehydrogenase polymorphisms and the risk for alcoholism. Am J Psychiatry $1995 ; 152$ : 1219-21.

30) Xu Y, Carr L, Bosron WF, Li TK, Edenberg HJ. Genotyping of human alcohol dehydrogenases at the $\mathrm{ADH} 2$ and $\mathrm{ADH} 3$ loci following DNA sequence amplification. Genomics $1988 ; 2$ : 209-14.

31) Harada S, Agarwal DP, Goedde HW. Aldehyde dehydrogenase polymorphism and alcohol metabolism in alcoholics. Alcohol $1985 ; 2$ : 391-2.

32) Saito S, Ikegami N. KAST (Kurihama Alcoholism Screening Test) and its applications. Jpn J Stud Alcohol $1978 ; 13: 229-37$.

33) Takeshita T, Maruyama S, Morimoto K. Relevance of both daily hassles and the ALDH2 genotype to problem drinking among Japanese male workers. Alcohol Clin Exp Res 1998 ; 22 : 115-20.

34) Higuchi S, Matsushita S, Muramatsu T, Hayashida M. Alcohol and aldehyde dehydrogenase genotypes and drinking behavior in Japanese. Alcohol Clin Exp Res $1996 ; 20$ : 493-7.

35) Morimoto K. Chromosome alterations in peripheral lymphocytes as indices of lifestyle and genotoxicity. Int Arch Occup Environ Health 1993 ; 65 : S37-S41.

36) Morimoto K, Takeshita T. Low $\mathrm{K}_{\mathrm{m}}$ aldehyde dehydrogenase (ALDH2) polymorphism, alcoholdrinking behavior, and chromosome alterations in peripheral lymphocytes. Environ Health Perspect 1996 ; 104(Suppl 3) : 563-7.

37) Böhlke JU, Singh S, Goedde HW. Cytogenetic effects of acetaldehyde in lymphocytes of Germans and Japanese: SCE, clastogenic activity, and cell cycle delay. Hum Genet 1983 ; 63 : 285-9.

38) Nakajima M, Takeuchi T, Takeshita T, Morimoto $K$. 8-Hydroxydeoxyguanosine in human leukocyte DNA and daily health practice factors: Effects of individual alcohol sensitivity. Environ Health Perspect $1996 ; 104: 1336-8$.

39) Woutersen RA, Appelman LM, Van GHA, Feron VJ. Inhalation toxicity of acetaldehyde in rats. III. 
Carcinogenicity study. Toxicology $1986 ; 41: 213-$ 31.

40) Takeshita T, Kawai T, Morimoto K. Elevated levels of hemoglobin-associated acetaldehyde related to alcohol drinking in the atypical genotype of low $\mathrm{K}_{\mathrm{m}}$ aldehyde dehydrogenase. Cancer Res $1997 ; 57$ : 1241-3.

41) Peterson CM, Polizzi CM. Improved method for acetaldehyde in plasma and hemoglobin-associated acetaldehyde: results in teetotalers and alcoholics reporting for treatment. Alcohol $1987 ; 4: 477-80$.

42) Yokoyama A, Muramatsu T, Ohmori T, Higuchi S,
Hayashida M, Ishii H. Esophageal cancer and aldehyde dehydrogenase-2 genotypes in Japanese males. Cancer Epidemiol Biomarkers Prev 1996 ; $5: 99-102$.

43) Yokoyama A, Muramatsu T, Ohmori T, et al. Alcohol-related cancers and aldehyde dehydrogenase-2 in Japanese alcoholics. Carcinogenesis $1998 ; 19: 1383-7$.

44) Takao A, Shimoda T, Kohno S, Asai S, Harada S. Correlation between alcohol-induced asthma and acetaldehyde dehydrogenase-2 genotype. J Allergy Clin Immunol 1998 ; $101: 576-80$. 